\title{
Classificação e frequência das lesões podais em rebanho ovino
}

Isadora Naomi Vieira Ogawa, Marcela dos Santos Ribeiro, Aline TramontiniZanluchi Queiroz, Jeycy Kelle Sirqueira Mendonça, Renato Manfrinato Florio, Gustavo Rodrigues Queiroz

Universidade Norte do Paraná (UNOPAR), Londrina, PR, Brasil

*Autor correspondente

e-mail: gustavorodriguesqueiroz11@gmail.com

\section{Resumo}

Problemas nos dígitos e espaço interdigitais dos ovinos são muito comuns, e são importantes causas de prejuízo econômico para a ovinocultura mundial. A correta identificação das lesões podais é a primeira medida para conseguir efetuar o tratamento e as medidas profiláticas apropriadas. No Brasil existem poucas informações sobre a ocorrência e a classificação das lesões podais em ovinos. 0 objetivo deste trabalho foi classificar e descrever a frequência das lesões podais de um rebanho ovino. Foram examinados 312 ovinos mestiços Santa Inês de diferentes idades, em uma propriedade no município de Jaboticabal, estado de São Paulo. Os animais eram mantidos em pasto de Tifton (Cynodon dactylon) durante o dia e confinados durante a noite. Todos os cascos e estruturas adjacentes foram limpos e uma fina camada da sola do casco foi retirada para facilitar o exame e a observação das lesões da região da sola e da linha branca. Foram examinados 2.496 dígitos e foram diagnosticadas 256 lesões. Apenas 94 (30,1\%) ovinos apresentavam lesões podais. Os membros posteriores (145/256; 56,7\%) apresentavam mais lesões do que os membros anteriores (111/256; 43,3\%). Dentre as lesões diagnosticadas, a dermatite interdigital (116/256; 45,3\%) foi a doença mais frequente e ocorreu mais no espaço interdigital dos membros posteriores $(67 / 116 ; 57,7 \%)$ do que nos anteriores (49/116; 42,3\%). A doença da linha branca foi observada em 63 (24,6\%) dígitos, ocorreu mais nos membros posteriores $(33 / 63 ; 52,4 \%)$ do que nos membros anteriores $(30 / 63 ; 47,6 \%)$ e a distribuição desta lesão entre os dígitos laterais e mediais foi de 49,2\% e 50,8\%, respectivamente. A podridão dos cascos (footrot) foi observada em 44 dígitos $(17,2 \%)$ e sua frequência foi maior nos dígitos dos membros posteriores $(28 / 44 ; 63,6 \%)$ do que nos anteriores $(16 / 44 ; 36,4 \%)$. Lesões como laminite séptica difusa $(6 / 256 ; 2,3 \%)$, alterações crônicas da articulação interfalangeana distal $(5 / 256 ; 1,9 \%)$ e efissura na muralha do casco $(4 / 256 ; 1,5 \%)$ foram observadas com menor frequência. Outras lesões ocorreram de 
maneira esporádica e somaram 7,0\% (18/256). As lesões observadas neste rebanho foram principalmente de origem infecciosa, como a dermatite interdigital e a podridão dos cascos, e de origem nutricional, como a doença da linha branca. Estes resultados demonstram a necessidade de classificar as lesões para realizar as medidas preventivas adequadas. 